\title{
The Implication of REDD+ in Community Forestry (CF) Governance and Local Livelihood: A Case from Nepal ${ }^{1}$
}

\section{Deepak Gautam, Garima Sharma, Rajesh Sigdel, Chitra Rekha Basyal, and Suruchi Mainali}

\begin{abstract}
Nepal's decentralized forest governance has now included a new actor, i.e. REDD+ which is a mechanism based on market for mitigation of climate change through conservation of forest. This paper aims to shed lights on the REDD+ effect on community forestry governance, and local livelihood. For this various published articles and reports were reviewed and analyzed. Organizations like ICIMOD, FECOFUN and ANSAB are leading a pilot project in community forestry on measurement of carbon and equalizing benefit. The major objective of the REDD+ program is to reduce forest carbon emissions by providing financial incentives for developing countries. The impacts of the implication of the $R E D D+$ is more questionable preceding its $10^{\text {th }}$ anniversary. Special income generating activities and awareness programs have been implemented by the REDD+ pilot project targeting the poor, women, disadvantaged groups and indigenous people. While some study findings show the REDD+ gave priority to the carbon outcome rather than community forestry's forest management objective which threatens the objective of meeting the local needs of people. Analysis also showed that REDD+ policies have been developed and interventions are made in a way local people's participation and representation of their voices is limited which may weaken and reverse the trend of forest decentralization. The involvement of the new actors in forest politics can be seen as a proof of positive impact of implementation of REDD+.
\end{abstract}

\footnotetext{
${ }^{1}$ Cite this article as: Gautam, D., et al. (2021). Contemporary Research: An Interdisciplinary Academic Journal, vol. 5 (1) DOI: https://doi.org/10.3126/craiaj.v5i1.40480

Deepak Gautam, Garima Sharma, Rajesh Sigdel, Chitra Rekha Basyal, and Suruchi Mainali; Institute of Forestry, Tribhuvan University, Nepal; Email: deepakgautamiof@gmail.com (corresponding author) Article history: Received on May 20; Accepted on August 23; Published on October 21

Peer reviewed under the authority of CRAIAJ, academic journal of Ghodaghodi Multiple Campus, Kailali, Nepal, with ISSN 2717-4611 (Print) and ISSN 2717-462X (Online).

(C) 2021 CRAIAJ
}

Full text of this article can be downloaded from www.craiaj.com and www.nepjol.info 
Key words: Carbon emissions; Carbon stock; Carbon tenure; Deforestation

\section{Introduction}

The role of forest has been recognized important for climate change mitigation through sequestration and storage of carbon (Godar Chhetri, 2012). Reducing emissions from deforestation and forest degradation, and enhancing forest carbon stocks (REDD+) is a new mechanism for offsetting of forest carbon (Khatri, 2013). The REDD+ mechanism has been the foremost real international effort to form a global forest governance system that would influence on national, regional and local scales of countries (Bayrak and Marafa, 2016). REDD+ has been adopted as a strategy to support actions which helps in mitigation of contributions from forestry sector to climate change (Pandit et al., 2017). Also, if REDD+ is carefully designed other additional benefits can be provided for improvement of livelihoods of community (Angelsen and Mcneill, 2012) and conservation of biodiversity (Venter et al., 2009).

As it is concerned with both the deforestation drivers and local livelihood, REDD+ has been a socio-economic as well as political scheme beyond carbon (Poudyal et al., 2013). For the developing countries like Nepal, REDD+ acts as a source of funding for solving problems related to deforestation, climate change, poverty, and biodiversity loss. However, close examination of its implications for forest governance, local level institutions and communities dependent on forests in definite national and local contexts is lacking (Bushley and Khatri, 2011).

Nowadays some kind of controversy is arising with the implication of REDD+ on forest governance. Some of the claims regarding REDD+ are that it improves governance and vitalize attempts of global conservation (Wollenberg and Springate-Baginski, 2010) while others claim as market value of the forest will be increased substantially after the implementation of REDD+. Local-level failures may lead to nonpayment risk so to avoid it, there is a chance that thecentral government will be encouraged to increase control in the forest (Phelps et al., 2010)thereby reversing the forest governance devolution trends (Bushley and Khatri, 2011). Thus, the study aims to compile the information on the REDD+ effect on community forestry governance, and local livelihood in Nepal. The attention was paid on the involvement of REDD+ on different aspect like CF decentralization, carbon tenure, biodiversity, livelihood, etc. It will help to disseminate knowledge regarding to REDD+. 


\section{Methodology}

This review article was prepared by assembling the data collected from online portals and published reports (Lamichane et al., 2021). Key words like REDD+, Governance, Community forestry, local livelihoods, etc. were used to gather the articles. A total of 50 articles were gathered and relevant 32 articles were further analyzed to make a paper. The complete process is given in the PRISMA flow chart in figure 1.

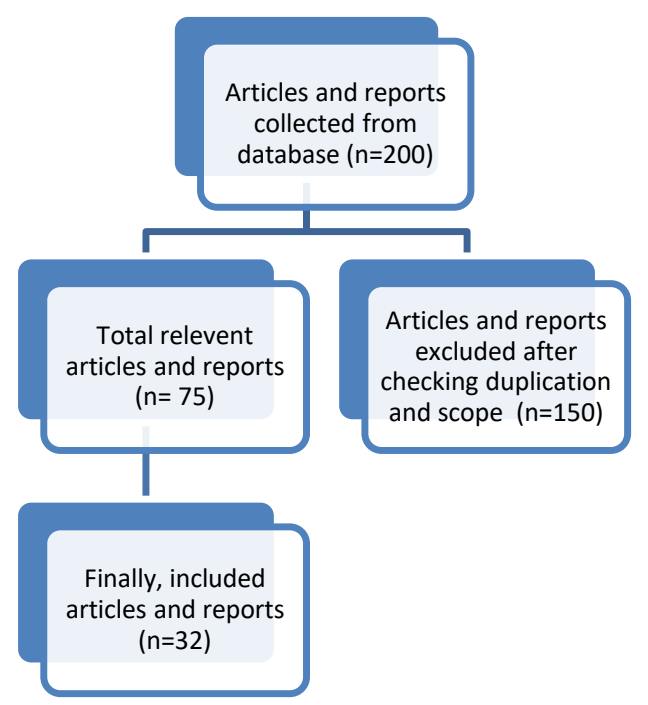

Figure 1: PRISMA flow chart for the analysis of RED++ effect on CF governance and livelihood

\section{Results and Discussion}

RED, REDD and REDD+ concept, their importance and implication

First of all, RED was discussed in 2005 which focused on reducing emission from deforestation at the UNFCCC's 11th conference of the parties (CoP), later RED included both deforestation and forest degradation (REDD) (Bayrak and Marafa, 2016). Finally, in the CoP 13 in Bali, Indonesia the initiative became REDD+ which included sustainable forest management, conservation and enhancement of forest carbon goals (Bayrak and Marafa, 2016). Several local level civil society groups and international organizations 
have been involved in REDD+ readiness process to validate its social and technical viability through implementation of various piloting activities (Khatri, 2013). The developing country and stakeholders get financial compensation due to their contribution in carbon sequestration (climate change mitigation) in their forests through sustainable management, use and conservation (Arts et al., 2019). REDD+ was initially known as "the world's largest experiment in Payments for Ecosystem Services” (Corbera, 2012) but now known as results-based aid (Angelson, 2017). Emission reductions calculation based on forest reference level of emission (CO2 emission in tones in particular year) is used to measure REDD+ performance (Arts et al., 2019).

\section{REDD+ and CF Governance}

Phelps et al. (2010) stated "By monetizing forest carbon, REDD+ will substantially increase the market value of forests, including those previously considered marginal, incentivizing central governments to increase control". Government can portray them as more skillful and trustworthy than the local people in terms of managing forest. They can try their best to avoid the threat of REDD+ nonpayment due to local-level failure (Phelps et al., 2010). The trend of decentralization can be reversed as REDD+ monitoring technical complexity required more centralized governance. (Khatri, Maskey, et al., 2018),in their study also claimed that although CF has strengthened due to increased income source, REDD+ interventions can weaken decentralization of CF by giving limited rights in the CFUGs' decisions. Also, REDD+ funding mechanism may incite the governments to reverse the trend of decentralization towards a centralized forest governance system for the purpose of reaping rewards more centrally (Sandbrook et al., 2010).Analysis also showed that REDD+ policies have been developed and interventions are made in a way local people's participation and representation of their voices is limited which may weaken and reverse the trend of forest decentralization (Bushley and Khatri, 2011; Ojha et al., 2013; Khatri et al., 2018).

Implementation of REDD+ has helped to build up community forestry in many countries and advantage from their past achievements and established institutional mechanisms (Newton et al., 2015). As it approaches its 10th anniversary, the impacts of the implication of the REDD+ is more questionable. The implication of REDD+ have both positive as well as negative impacts. It can bring both opportunities and constraints to Community Forest Management (CFM) by restructuring forest management activities and 
community forest landscapes. On one side, REDD+ may make the forest conservation activities financially sustainable and improve forest management by increasing the administrative, economic, and technical resources in community forest institutions (TFCG, 2009; RECOFTC, 2011). While on the other, the implementation of the REDD+ programs comes with a set of complications too and even threaten the integrity of community forestry (Newton et al., 2015).

\section{Community forestry governance in Nepal}

Three stages of forestry in Nepal as stated by analysts are - till 1957 (privatization), 1957 to 1970s (nationalization), and from 1970s onward (decentralization) (Hobley, 1996). In Nepal, before 1957, Ranas used to take control over the forest, local people had only limited rights to utilize forests resources (Gilmour and Fisher, 1991).In 1957, the nationalization act was implemented where most privately held forest lands were nationalized by government. The first institutional shift occurred when Panchayat forest and Panchayat protected forest regulation 1978 was endorsed which gave limited rights to local bodies (Ojha et al., 2009). Since the early 1980s, decentralized mode of forest governance called community forestry has taken root (Bushley and Khatri, 2011). In 1993, a new forest act was enacted which granted rights to local people for forest management (Ojha et al., 2009). This decentralized mode of forest governance has included the policies and processes among government agencies, forging of new roles, communities, civil society, and the private sector (Bushley and Khatri, 2011). Role of meso bodies in governance has improved after Forest Act 1993 (Banjade et al., 2007) and intermediary connections like FECOFUN bridges the gap between people and state (Ojha et al., 2009).

Community forestry involves the local people in forest management which enables them to manage and utilize the forest products. CFUGs are generating income through sale of forest products and utilizing them in forest management and community development activities (Kanel and Kandel, 2004). CF has enriched the greenery and growing stock. But the government managed forests are depleting and degrading (Kanel and Dahal, 2008).

\section{The Implication of REDD+ on CF governance in Nepal}

Nepal's decentralized forest governance has now included a new actor, i.e., REDD+ which is a mechanism based on market for mitigation of climate change through conservation of forest (Khatri, 2013). The Ministry of Forests and Soil Conservation (MoFSC) (now Ministry of Forest and Environment MoFE) led Nepal's REDD+ strategy 
by developing a national Readiness Preparation Proposal (R-PP) (MoFSC, 2010). Several organizations like ICIMOD, FECOFUN and ANSAB are leading a pilot project in community forestry on measurement of carbon and equalizing benefit (Khatri, Marquardt, et al., 2018). From 2009 to 2013 in Nepal, REDD+ piloting projects were first executed in 105 community forests in three districts-Dolkha, Gorkha and Chitwan (Shrestha et al., 2014).

\section{REDD+ and local livelihood}

Devkota (2019) in his study stated that the REDD+ pilot project targets the poor, women, disadvantaged groups and indigenous people through its special income generating activities and awareness programs. For deprived and medium-class users revenue generating activities were executed in both Kankali CFUG and Janapragati CFUG. In CFUGs, the disadvantaged group's representation in the executive committee has improved, though they feel that their voices do not impact the decision on CFUG and benefit sharing (Devkota, 2019).According to (Khatri, Maskey, et al., 2018), the REDD+ pilot project mandate the CFUGs to spent at least $50 \%$ of carbon payment funds in poverty minimization and livelihood upliftment activities targeting disadvantage groups, as these activities were included in the Forest Carbon Trust Fund (FCTF) Operational Guidelines. Additionally, CFUGs has practiced various climate change adaptation measures to cope with climate change (Godar Chhetri, 2012). About REDD+ 50\% income was invested for livelihood improvement projects and for CFUG's administration and training activities the rest $10 \%$ of the payment was used (Khatri, Maskey, et al., 2018; Shrestha et al., 2014).While some study findings show that the carbon centered interventions like REDD+ gave priority to the carbon outcome as it is a payment mechanism rather than community forestry's forest management objective which aims to meet the local needs of people (Khatri, Marquardt, et al., 2018). Also, lack of attention in safeguarding the local people as well as marginalized communities rights, and interests reflected in REDD+ policy documents (MoFSC, 2010).

\section{REDD+ and carbon tenure}

Another constant issue prevailing in Nepal's community forest is forest tenure. In Terai, there is unsettled forest tenure and management modalities conflicts (Ojha et al., 2009). With the emergence of REDD+ in the community forestry new debates have aroused regarding the forest carbon right. Some say that REDD+ threaten the forest tenure while some view it as an opportunity which can further secure forest tenure rights. Nasi et 
al. (2011)say that REDD+ can be an opportunity and express: "REDD+ could provide big incentives to clarify tenure, alleviating the existing low interest of establishing clear rights because of the widespread inability to recognize fully forest values” (p. 205). Under other conditions, Lemaitre reasons that REDD+ adds importance of the forest which encourages government to take control over the forest and exclude indigenous people denying their traditional land rights (Bayrak and Marafa, 2016). According to MFSC (2010), "Forest carbon exists both within plants and within the soil; thus, ownership rights to forest is contentious in community forests where ownership of the forest biomass and the underlying land rests with two separate entities". Thus equitable benefit sharing seems quite challenging in this situation where government and communities share forest rights. The government may claim its right for soil carbon's revenues(Newton et al., 2015). Elite would be incited by the cash flow in communities and capture the benefits even when the community level is involved in decision making affecting the marginal groups (Toni, 2011).

\section{REDD+ and various actors}

Also talking about the positive aspect of REDD+ implementation, some evidence shows that governance is reshaping in subtle ways by REDD+ readiness process. The foremost thing that can be seen is the new collaboration among the civil society although their effectiveness is yet to be determined. Also, the involvement of the new actors in forest politics can be seen as a proof of positive impact of implementation of REDD+ (Bushley and Khatri, 2011). For instance, the involvement of NEFIN which was little before REDD+ has increased in forestry dialogues and forums after the REDD+. The involvement of the civil society organizations (CSO) although a gradual or uneven one has seemed to be increased in different aspects like pilot monitoring, policy making awareness raising about the climate change and carbon offsetting. However, their influence is seen minimal on institutional design outcomes (Bushley and Khatri, 2011). Here civil society organization drawn to the REDD+ discourses of conserving carbon is seen as the positive aspect of REDD+ implementation, but various study also argues that the involvement of civil society has left narrow space for voices of local people to be heard and mirrored in the national policy processes (Ojha et al., 2013). 


\section{Major challenges associated with REDD+}

The carbon centered mechanisms i.e. REDD+ has a great risk of threatening biodiversity in several ways. First of all, forests are changing into monoculture or forest plantation which tends to increase the carbon outcome while putting biodiversity and socio-cultural values at stake (Agrawal et al., 2011; Reed, 2011). Also these interventions have the potential risk of undermining the several ecosystem services that the local people usually depend upon (Khatri, Maskey, et al., 2018). Bushley and Khatri (2011) in their study state that governance is a concerned issue in the REDD+ debates, the current REDD+ readiness process lacks safeguards and mechanisms for monitoring to confirm the benefits from the biodiversity and effective decentralized forest governance. Also, technobureaucrats control the various piloting activities and pervade the policy process too. Pilot projects have been intensively making efforts for carbon stocks monitoring and imparting the knowledge to community members, but the project activities do not take into account the discussions on safeguarding the impacts of REDD+ involvement in the forest for biodiversity and local livelihood (Bushley and Khatri, 2011).

\section{Conclusion}

The study showed that the REDD+ is a payment mechanism and increase the value of the forest. The objectives of the REDD+ mechanism tends to ignore the community forestry objective, i.e., meeting the needs of local people. The major debatable issue found about REDD+ was that this mechanism is likely to weaken the CF decentralization. There is controversy on forest tenure rights as some say REDD+ is an opportunity that can secure the forest tenure right, while the others say it can threaten. REDD+ is also seen as a mechanism which threatens the biodiversity of the forest as it encourages carbon monoculture that undermines the multiple benefits of the ecosystem which local people depend upon. REDD+ has increased involvement of different sectors i.e. CFUGs, civil societies, NGOs, INGOs etc in forest management. However, the involvement of the various civil society organizations in techno-bureaucratic approach prevails in the policy process and piloting activities like accessing and monitoring carbon stocks has left limited space for the participation of local people. The representatives of the disadvantaged group have increased, but not necessarily their voices are being heard. 


\section{References}

Agrawal, A., Nepstad, D., \& Chhatre, A. (2011). Reducing emissions from deforestation and forest degradation. Annual Review of Environment and Resources, 36, 373396.

Angelsen, A. (2017). REDD+ as result-based aid: General lessons and bilateral agreements of Norway. Review of Development Economics, 21(2), 237264.https://doi.org/10.1111/rode.12271

Angelsen, A., \& Mcneill, D. (2012). A. and McNeill, D. 2012. The Evolution of REDD+. Analysing REDD+: Challenges and Choices. CIFOR, Bogor, Indonesia.

Arts, B., Ingram, V., \& Brockhaus, M. (2019). The performance of REDD+: From global governance to local practices. Forests, 10(10), 837. https://doi.org/10.3390/f10100837

Banjade, M. R., Paudel, N. S., Ojha, H., McDougall, C., \& Prabhu, R. (2007). Conceptualising meso-level governance in the management of commons: Lessons from Nepal's community forestry. Journal of Forest and Livelihood, 6(1), 48-58.

Bayrak, M., \& Marafa, L. (2016). Ten Years of REDD+: A Critical Review of the Impact of REDD+ on Forest-Dependent Communities. Sustainability, 8(7), 620. https://doi.org/10.3390/su8070620

Bushley, B. R., \& Khatri, D. B. (2011). REDD+: Reversing, reinforcing or reconfiguring decentralized forest governance in Nepal. Forest Action, 3.

Corbera, E. (2012). Problematizing REDD+ as an experiment in payments for ecosystem services. Current Opinion in Environmental Sustainability, 4(6), 612619.https://doi.org/10.1016/j.cosust.2012.09.010

Devkota, B. (2019). From participation to responsiveness: The changing priorities of community forestry governance in Nepal`s Terai. Dissertationes Forestales, 2019(282). https://doi.org/10.14214/df.282

Gilmour, D. A., \& Fisher, R. J. (1991). Villagers, forests, and foresters: The philosophy, process, and practice of community forestry in Nepal.

Godar Chhetri S. (2012).Climate change, its impacts on rural livelihood: adaptation strategies from Siwalik to Terai region. Lambert Academic Publishing, Mauritius

Hobley, M. (1996). Participatory forestry: The process of change in India and Nepal. Overseas Development Institute (ODI). 
Kanel, K. R., \& Dahal, G. R. (2008). Community forestry policy and its economic implications: an experience from Nepal. International Journal of Social Forestry, 1(1), 50-60.

Kanel, K. R., \& Kandel, B. R. (2004). Community forestry in Nepal: Achievements and challenges. Journal of forest and Livelihood, 4(1), 55-63.

Khatri, D. B. (2013). Is REDD+ Redefining Forest Governance in Nepal? Journal of Forest and Livelihood, 10(1), 74-87. https://doi.org/10.3126/jfl.v10i1.8602

Khatri, D. B., Marquardt, K., Pain, A., \& Ojha, H. (2018). Shifting regimes of management and uses of forests: What might REDD+ implementation mean for community forestry? Evidence from Nepal. Forest Policy and Economics, 92, 110. https://doi.org/10.1016/j.forpol.2018.03.005

Khatri, D. B., Maskey, G., \& Adhikari, B. (2018). REDD+ and Community Forestry in Nepal: Strengthening or Paralysing Decentralised Governance? Journal of Forest and Livelihood, 16(1), 35-55.

Lamichhane, R., Gautam, D., Miya, M.S., Chhetri, H.B., \& Timilsina, S. (2021). Role of Non-Timber Forest Products in National Economy: A Case of Jajarkot District, Nepal. Grassroots Journal of Natural Resources, 4(1), 94-105. https://doi.org/10.33002/nr2581.6853.040107

MoFSC, 2010. Nepal's Readiness Preparation Proposal REDD 2010-2013. Ministry of Forests and Soil Conservation, Kathmandu

Nasi, R., Putz, F. E., Pacheco, P., Wunder, S., \& Anta, S. (2011). Sustainable forest management and carbon in tropical Latin America: The case for REDD+. Forests, 2(1), 200-217.

Newton, P., Schaap, B., Fournier, M., Cornwall, M., Rosenbach, D. W., DeBoer, J., Whittemore, J., Stock, R., Yoders, M., Brodnig, G., \& Agrawal, A. (2015). Community forest management and REDD+. Forest Policy and Economics, 56, 27-37. https://doi.org/10.1016/j.forpol.2015.03.008

Ojha, H., Persha, L., \& Chhatre, A. (2009). Community forestry in Nepal: A policy innovation for local livelihoods. Proven Successes in Agricultural Development, 123.

Pandit, R., Neupane, P. R., \& Wagle, B. H. (2017). Economics of carbon sequestration in community forests: Evidence from REDD+ piloting in Nepal. Journal of Forest Economics, 26, 9-29. 
Phelps, J., Webb, E. L., \& Agrawal, A. (2010). Does REDD+ threaten to recentralize forest governance? Science, 328(5976), 312-313.

Poudyal, B. H., Paudel, G., \& Luintel, H. (2013). Enhancing REDD+ Outcomes through Improved Governance of Community Forest User Groups. Journal of Forest and Livelihood, 13.

RECOFTC, I. (2011). REDD-Net. 2011."REDD+ Governance, and Community Forestry: Highlights from the Forest Governance Learning Group Asia Experts Meeting,.” RECOFTC, IIED, REDD-Net, Bangkok.

Reed, P. (2011). REDD+ and the indigenous question: A case study from Ecuador. Forests, 2(2), 525-549.

Sandbrook, C., Nelson, F., Adams, W. M., \& Agrawal, A. (2010). Carbon, forests and the REDD paradox. Oryx, 44(3), 330-334.

Shrestha, S., Karky, B. S., \& Karki, S. (2014). Case study report: REDD+ pilot project in community forests in three watersheds of Nepal. Forests, 5(10), 2425-2439.

TFCG, 2009. Making REDD Work for People and Forest in Tanzania: Lessons Learnt From Participatory Forest Management in Tanzania. Tanzania Forest Conservation Group, Dar es Salaam.

Toni, F. (2011). Decentralization and REDD+ in Brazil. Forests, 2(1), 66-85.

Venter, O., Laurance, W. F., Iwamura, T., Wilson, K. A., Fuller, R. A., \& Possingham, H. P. (2009). Harnessing carbon payments to protect biodiversity. Science, 326(5958), 1368-1368.

Wollenberg, E., \& Springate-Baginski, O. (2010). REDD, forest governance and rural livelihoods: The emerging agenda. CIFOR. 